\title{
A participatory model of creating revitalisation programmes in Poland - challenges and barriers
}

\section{Dominika Hołuj, Paulina Legutko-Kobus}

\begin{abstract}
Participation is an indispensable element of the development and implementation of revitalisation programmes. It allows for a correct diagnosis of problems and for the development of revitalisation projects that will aim at solving them. The implementation of the Revitalisation Act in Poland obliged local governments to involve stakeholders more actively in the process of preparation and implementation of revitalisation programmes. The Act guarantees participation at every key stage of the process. In current Polish circumstances this is a change in the right direction, as such participation was not always ensured in previous financial perspectives. However, the law does not guarantee that a participation process is real and efficient rather than only "checking off" the procedural requirements. Based on these premisses, this article discusses the subject of participation in revitalisation programmes, both in theoretical terms (how participation in a revitalisation can be organised; considering the legal conditions, what obstacles to the implementation of a participatory approach to the development of revitalisation programmes can be diagnosed in Poland) and the practice of programming in selected cities of the Lesser Poland and Mazovia regions (what forms and tools of participation were used at each stage of the revitalisation programme development, does the scope of participation influence the structure of revitalisation projects).

Such research objectives determine the research methods used to prepare this article, i.e. a critical analysis of the source literature pertaining to the subject, web and desk research, a comparative analysis of the revitalisation programmes of selected cities, an analysis of the results of an Internet survey among city authorities and participatory observation.
\end{abstract}

Key words: participation, revitalisation, stakeholders, social capital

\section{Introduction}

Currently, revitalisation is understood as a comprehensive, coordinated and participatory process of "bringing back to life". In the source literature, we can find various definitions of this process, but their common element is the recognition that revitalisation is required in areas with a complex structure of problems: economic, material, functional, spatial, compositional, social, environmental and with public image. Concurrently, these areas are characterised by a lack of sufficient internal potentials allowing for the initiation of selfrepair processes. Thus, an external intervention is necessary for the process of change to begin [Lorens 2010, p. 10-11; Kozłowski, Wojnarowska 2011, p. 16; Markowski 2007, p. 325; Skalski 2007, p. 68; Kopeć 2010, p. 69, pp. 121-122; Domański, Gwosdz 2010, p. 51; Parysek 2005, p. 166 et seq.; Kaczmarek 2001, pp. 22-23; Rydzik 2009, p. 166]. The revitalisation process cannot be considered as a standalone activity (e.g. by local authorities), but it should 
be carried out cooperatively as the coordinated actions of many entities [Ziobrowski 2010, p. 8]. These actors include local authorities and communities, economic entities, the third sector and any other group, which may have a significant impact on the changes occurring in a given area or which may be affected by those changes.

The complexity of urban renewal problems, already visible at the level of defining the process, indicates that it cannot be narrowed down to renovation, restructuring, regeneration, revalorization, restoration, modernisation and rehabilitation. Revitalisation is in this respect an overarching notion and process [Boryczka 2016b, pp. 168-169; Markowski 2015, p. 293], whereas its area is only a medium through which this process can take place [Bukowski 2014]. Its essence should lie in the renewal of social potential, as the term revitalisation indicates.

Based on these premisses, the authors analysed the importance of participation in the development of revitalisation programmes. This article focuses on answering the following research questions:

- how can participation in the process of revitalisation be organised?

- what obstacles to participation can be identified in Poland?

- what forms of participation were applied in the development of revitalisation programmes in selected cities of Lesser Poland and Mazovia?

- does the scope of participation translate into the structure of revitalisation projects?

Such research objectives determine the research methods used to prepare the article, i.e. critical analysis of the source literature, web and desk research, comparative analysis of revitalisation programmes in selected cities, analysis of the results of an online survey addressed to cities and participant observation.

\section{Participation as an element of the revitalisation process - a theoretical approach}

Social participation, defined as communal or horizontal engagement, is the participation of individuals in collective actions undertaken in a community to which they belong and in which they live. It consists of such activities as the creation and functioning of civic groups and non-governmental organisations. Public participation is defined as the involvement of individuals in the functioning of institutions and structures of a democratic state [Lewenstein, Schindler, Violin, 2010; Kaźmierczak 2011, p. 18; Długosz, Wygnański 2005]. Civic participation is considered to be the basis for participatory governance. Participation should be a permanent element of revitalisation (it should be a process, not incidental activities), while its scope and forms should be selected in such a way that the objectives of participation can be accomplished as fully as possible. This can be achieved first of all by reaching a consensus among partners in order to achieve the objectives of comprehensive revitalisation. It is extremely important that organising the participatory activities is not only a goal in and of itself or the just fulfilment of procedural obligations [Creighton 2005]. In this view, participation is not a procedure, but an element of a social dialogue that assumes joint decision-making and cooperation [Florys, Gałek, Jarzębska, Kazior 2016, pp. 7-8]. 
In the revitalisation process we can observe a merging of social, public and obligatory (resulting from the provisions of law) participation. This is due to the fact that delimiting a degraded area and then the area subject to revitalisation, i.e. the basis of development of revitalisation programmes and consequently for intervening in the degraded areas, requires not only an expert approach (implementation of methods of comparative and ratio analysis) but, first and foremost, reaching social consensus and acceptance for the selected objectives of revitalisation and proposed projects. By becoming a subject (and not only an object) of revitalisation, a local community uses the space, fulfiling its needs in it [Górski 2016, p. 91]. Therefore, diagnosing and then solving social problems is also a condition for maintaining the external, spatial result achieved (often with substantial financial means). Social problems that are not solved often lead to regression, i.e. rapid decapitalisation of the resource [Grabowski 2014 , p. 147]. One should bear in mind that inclusion of social issues may also be somewhat flawed, focusing only on technocratic aspects (e.g. correct targeting of social benefits or monitoring their beneficiaries), and not on relations, attitudes and social problems [Theiss 2011, p. 46]. Based on these assumptions, it can be stated that participation is indispensable to the revitalisation process. Its scope and tools are first and foremost the direct consequence of the legal basis adopted for the development of the revitalisation programme.

During the current programming period (until 2020), a revitalisation programme in Poland may be based on 1 :

- The Act of 8 March 1990 on municipal government [ustawa z dnia 8 marca 1990 r. o samorzadzie gminnym] and the Guidelines on revitalisation in operational programmes for 2014-2020 [hereinafter referred to as Guidelines ${ }^{2}$ ] - in this case they are local revitalisation programmes, the revitalisation programmes of a municipality/city;

- The Revitalisation Act of 9 October 2015 - in this case they are municipal revitalisation programmes (MRP).

Regardless of the adopted legal basis, the area subject to revitalisation may not exceed $20 \%$ of the municipality's area and may not be inhabited by more than $30 \%$ of the municipality's population [Article 10 of the Revitalisation Act]. In both cases, it is emphasised that revitalisation is a process carried out by its stakeholders, such as: residents of the area subject to urban renewal; owners and perpetual usufructuaries of real estate; entities managing real estate located in the area, including housing cooperatives, tenants' associations and social housing associations [towarzystwa budownictwa społecznego]; other residents of the municipality; entities conducting or intending to conduct business in the municipality; entities conducting or intending to conduct social activity in the municipality, including NGOs; local governments and their organisational units; public authorities; entities exercising State Treasury rights.

\footnotetext{
${ }^{1}$ Not all Polish regions [województwa] allow local governments to choose the legal basis. For example, the Lesser Poland region allows only the Revitalisation Act to be used, while the local governments in Mazovia are free to choose the legal basis, taking into account that the local revitalisation programmes established on the basis of the Act on municipal government and the Guidelines will only be valid until 2023.

${ }^{2}$ The Guidelines [Wytyczne w zakresie rewitalizacji w programach operacyjnych na lata 2014-2020] were developed by the Ministry of Infrastructure and Development and have been in effect since 3 July 2015.
} 
In the case of a revitalisation programme based on the Act on municipal government and the Guidelines, participation results directly from the partnership principle which indicates that revitalisation is to be an open process, based on a permanent dialogue with all stakeholders. Participation must be a part of each stage of the revitalisation process, i.e. diagnosis, programming, implementation and monitoring, and it must not be limited to providing information and consulting the local authorities' activities, but should rather take the most advanced and mature forms, e.g. joint decision-making or civic control [Guidelines 2015, p. 6, 20, 24].

When a revitalisation programme is based on the Revitalisation Act, the aspects of participating in the process of preparing and implementing of the MRP are regulated in chapter 2 of the Act [Art. 5-7]. Since the Guidelines will only be in force for a limited period of time, eventually the participation in the revitalisation process will be conducted on the basis of the Revitalisation Act, i.e. in the model of obligatory participation.

Public consultations conducted in the process of MRP development are overseen by the municipality head. Pursuant to the provisions of the Act, they must include the following: collecting remarks submitted on paper or in electronic form, including all means of electronic communication, in particular e-mails or forms on the municipality's Public Information Bulletin [BIP] webpage. In addition, with reference to the local specificity and previous experience in terms of participation (e.g. related to the development of other local documents), there is a statutory obligation to use at least two other forms of consultation. The municipality/ city may, therefore, carry out the consultations in the form of meetings, debates, workshops, study walks, surveys, interviews with representative groups or collection of oral comments. It is crucial that information about when and in what form such social consultations will take place is provided no later than 7 days in advance. The Act also specifies that the information is to be provided in a manner ensuring the participation of as wide a range of stakeholders as possible (at least through an announcement, a notice published in a customary manner specific to a given municipality and an announcement posted to the Public Information Bulletin on a municipality's website [Article 6.2. of the Revitalisation Act]). The provisions of the Act also require that drafts of the consulted documents and results of consultations are available in the Public Information Bulletin.

A Revitalisation Committee is an important new element introduced by the Act. It is to be a forum for cooperation and dialogue between stakeholders and municipality bodies dealing with the preparation, implementation and evaluation of revitalisation. The Committee acts as a consultative and advisory body to a municipality head. It is appointed by a decree of the municipality head and should consist of representatives of all stakeholders involved in the revitalisation.

To sum up, it should be noted that a properly conducted participatory process allows for a thorough diagnosis of the scope of problems in the area subject to revitalisation, not only determining a list of revitalisation objectives but also identifying the groups of stakeholders who need to be involved. Their inclusion in the revitalisation process translates into the 
representation of various points of view, needs, desired directions of action and changes. This contributes to the achievement of better results of the process [Domański 2010, p. 24; Ostrom 1996; OECD Territorial Outlook... 2001, p. 25]. The benefits of public participation include: better quality of decisions (better adjustment to the social needs); minimisation of costs and delays in the process implementation (although its preparation may be prolonged due to the application of participatory procedures); facilitation in the implementation of the revitalisation programme; the possibility of reaching a consensus, which enables potential conflicts to be diagnosed and at least partially eliminated or mitigated (although it does not guarantee they will be resolved). Participatory activities (above all, taking into consideration the results of participation) sustain the credibility and legitimacy of authority, indicate the authorities' socially-oriented attitude and contribute to the development of the civil society [Creighton 2005, pp. 18-19; Długosz, Wygnański 2005, p. 12]. Including various partners (business, the third sector, others) in the programming and implementation of public policies creates a combination of different potentials, which eliminates flaws of the administration (when it does not want, is not able or does not have sufficient resources to perform public tasks).

In order for the participation to bring the expected (assumed) effects, it must be carried out efficiently, i.e. it must meet the following conditions:

- the participation of stakeholders at each stage;

- defining the principles of the stakeholders' involvement (effective information policy; the process organiser creating a balance of power in which the external stakeholders feel needed, listened to; representation of different groups; interactive participation, not a one-way message);

- the equivalence of partners (which may be distorted if the authorities to a large extent decide on the financing of entities, e.g. the third sector );

- the recognition of the public authorities' legitimacy to make law and their responsibility for the decisions made (they are those ultimately responsible);

- the responsibility for expressed opinions, suggestions and views;

- a consensus-oriented attitude (the belief that all stakeholders have good intentions and their common goal is the wellbeing of the general public and not the interests of individuals; representatives of groups do not manipulate others);

- preparing partners for dialogue;

- the transparency of actions (established and respected principles);

- fairness (legality and equality of entities);

- a chosen and followed long-term course of action (supervised by the organiser of the process);

- taking into account the outcome of consultations [Schimanek 2015, p. 11, 24, pp. 69-75; Urbanik, Luber, Chrzanowski, Krzemińska 2012, p. 18; Yang, Graham, Amos, Plumptre 2003, p. 3; Boryczka 2016a, p. 118; Gawroński 2010, p. 31; Bleckley 2008, p. 34].

Factors that reduce the efficiency of participation may be related to the organisation of the process and the skills and knowledge of its participants. 
The organisation of the participatory process itself may be focused on the very fact of holding meetings (keeping up appearances) rather than achieving an effect (e.g. reaching a consensus). In such an approach, the participation is more of a marketing activity (an institution advertising its activities). In this case it is difficult to expect the participation process to bring the required results, especially if additional problems related to the preparation and implementation of the participatory process occur, i.e. focusing during consultation meetings on topics not related to the revitalisation, using incomprehensible expert language during consultations or the presence of information noise (e.g. when representatives of various units of local authorities say divergent things) [Wańkowicz 2013, p. 23; Jessop 2007, p. 10; Gawroński 2010, p. 28].

A different concept, determining whether the conditions for effective participation are met and enable its goals to be achieved, is the CLEAR model [Lowndes, Pratchett, Stoker 2006]. This notion takes into account the significance of elements such as the skills and knowledge of the process participants. The concept pays attention to the environment (surroundings) in which the participation will take place. The efficacy of the participation is strongly associated with the level and quality of social capital. The higher the level of the social capital, the bigger the chances for cooperation, solving social problems, applying the principle of subsidiarity and the better the diagnosis and possibilities of solving social problems [Theiss 2007, pp 9699]. However, it is difficult to conduct a dialogue in communities that are very diverse in terms of expectations, knowledge, attitudes [Participatory governance 2007, p. 7], in communities characterized by expectations of quick and lasting solutions to their problems (most often this is impossible in a short period of time), as well as in communities lacking historically consolidated participatory patterns [Participatory governance 2007, pp. 7-8; Robinson, Shaw, Davidson 2005, p. 16]. On the other hand, the authorities also affect the community's level of social capital and social participation in a public life.

Conditions allowing for the development of social capital and potential include:

- abiding by the rules (the authorities follow them and expect the same from others) the community gains confidence;

- creating a cooperation network (lasting, repeated relations, interactions, good information transfer);

- credibility (of the authorities, partners) [Grodzicki 2015, pp. 74-75].

As a summary to the deliberations on theoretical aspects of participation, it is worth noting that a decision, initiated by the local authorities, to involve stakeholders in the revitalisation process, is also associated with costs. These may include organisational and financial costs, as well as the need to provide additional time (e.g. to reach a compromise). However, judging from the research on participation, it should be considered a necessary cost. Analyses, discussions, and consultations should not take place under time pressure, especially when difficult and complex issues are being resolved [Schimanek 2015, pp. 10-11; Sześciło 2014, p. 239; Gawroński 2010, p. 31]. 


\section{Obstacles to participation in Poland - conditions under which the revitalisation programmes are prepared and implemented}

The revitalisation processes, in particular the participatory development of revitalisation programmes, are a component of a wider process related to the implementation of the ideas of civil society and governance. In general, the level of participation in Poland can hardly be considered satisfactory, therefore both public entities and the society are still learning how to organise and take part in participatory activities. It is a process with different dynamics (both in reference to the authorities and society), but also with different starting conditions [Kotus 2014, p. 44].

Social capital is the basic factor allowing for efficient participation, but in Polish conditions it is an obstacle. Its various measures (the social trust index, indicators of civic activity and indicators of participation in elections) refer to different types of participation. Regardless of the adopted method of analysis of the Polish social capital, its level is low [LegutkoKobus 2011; Social Diagnosis 2015]. The unsatisfactory level of social capital (resulting from historical circumstances and contemporary trends in civilisational development) leads to a low response rate to authorities' invitations to cooperation [Czyż 2016, p. 304; Rembarz 2016, p. 34; Kwiatkowski 2015, p. 99; Domański 2010, p. 26; Jasiecki 2015, p. 113]. Crisis situations are an exception to this rule [Rembarz, Martyniuk-Pęczek 2016, p. 126; DzieniszewskaNaroska 2011, pp. 116-126; Skrzypiec 2010, pp. 127-138; Olech, Sobiesiak- Penszko 2013, pp. 5-6; Domański 2010, p. 26; Hołuj 2014; Przywara 2013, p. 63; Gorączko 2016, p. 14; Noworól, Noworól, Hałat 2012, p. 27; Pawłowska 2012, p. 55]. This seems to confirm the hypothesis that actions for the common good in Poland are more action-oriented (incidental) than continuous and long-term in their nature [Jastrzębska, Legutko-Kobus 2014a].

The historical determinants of the low level of social capital are above all the result of longterm servile relations in Poland, a culture of civic involvement limited to the nobility, the short history of $20^{\text {th }}$-century sovereignty, and the period of central planning after World War II. For these reasons, there was no chance or circumstances for participation, a phenomenon dependent on long-term processes, to be established as a practice of involvement in Polish public life in "times of peace". This results in the currently visible institutional deficiencies (the lack of ability to organise effective activities) and social deficiencies (a passive attitude towards the activity of the authorities).

The low level of social capital in Poland does not only stem from the historical conditions. Many researchers of the subject, people and institutions participating in the activities of public authorities, indicate that the main obstacle is the mistrust towards the authorities. It is manifested by uncertainty as to whether their commitment will bring any results and whether the conclusions reached and promises made will be taken into account during further stages of the process. This is due to the "misappropriation of the voice of the society": declaring a goal different from the actual use of the citizens' voice (e.g. it serves only to meet the legal requirements of consultation) [Czyż 2016, p. 304; Theiss 2010, p. 156; Sadura 2012; Pudełko 
2015, p. 101; Długosz, Wygnański 2005, p. 10; Rogaczewska, Chodacz, Hejda, Prędkopowicz 2014, p. 157; Nowak 2014, p. 67; Raport Końcowy... 2011, p. 143]. This mistrust towards the authorities often results from previous negative experiences with cooperation (in the current political system, after 1990). A possible participant perceives and assesses the local authorities as a whole. If he or she participated in any consultations and felt ignored or not fully listened to, then in many cases he or she no longer sees any point in engaging and participating [Hołuj, Hołuj 2016; Hołuj 2016]. The reluctance to participate in activities organised by the authorities is often also a symbolic manifestation of dissatisfaction [Szczegóła 2003, p. 20].

The low level of social capital in Poland is also characterised by a significant regional or even local level of diversification and a differentiation between urban and rural areas [Sztompka 2007]. This is particularly visible in civic participation as manifested by taking part in elections, but also in public participation measured by the activity of local non-profit organisations (which should serve as positive local lobbyists) or by participation in volunteering initiatives [Przywara 2013, p. 60; Stypułkowski 2012; Meisel-Dobrzański 2014, p. 77, 83; Jastrzębska, Legutko-Kobus 2014a]. Part of the society does not see the need to participate, believing that the problems occurring in an area (e.g. one subject to revitalisation) do not directly affect them [Czyż 2016, p. 304; Olech, Sobiesiak-Penszko 2013, p. 15; Noworól, Noworól, Hałat 2012, p. 27; Raport Końcowy... 2011, p. 143]. They may also consider participation superfluous when they see a possibility of obtaining benefits despite a lack of personal involvement (as a "stowaway") or when they believe that they are a customer of the authorities whose duty it is to provide citizens with services, transfers and solve emerging problems [Grabowska 2003, p. 190]. It should be added that the government is sometimes perceived to hold such a role both by citizens and by those in power.

The second significant obstacle to participation in Poland, resulting directly from the unsatisfactory level of social capital, is the immaturity, even weakness of the third sector. This results in the absence of an active and competent partner in participation. The situation in this respect is very diverse locally, as - especially in large cities - we are witness to a dynamic development of urban movements manifesting their disillusionment with the authorities, wishing not only to be regarded as passively expressing their needs and preferences [Rembarz, Martyniuk-Pęczek 2016, p. 128; Solon-Lipiński 2015; Baranowska, Frankowski, Grabkowska, Sagan 2014, pp. 122-123; Billert 2014, p. 123]. Cooperation between urban movements and public authorities (if it takes place) offers opportunities for the integration of the social and public potentials in order to solve the problems of an area. However, in order for it to produce results, in both cases it must be based on a solid base of knowledge, a long-term willingness to commit, and the application of the principles of complementarity, autonomy and treatment as entities, in the name of social utility [Mazur, Wygnański 2015, p. 26].

The third group of obstacles consists of errors in organising participation, resulting both from objective difficulties and lack of competences (both on the part of the local government and non-governmental organisations). Authorities, especially at the local level, are often 
characterised by a lack of knowledge in the field of participation. ${ }^{3}$ Some local authorities look for a remedy in an external professional base (it is easier to take advantage of them in larger cities, where there are such institutions as universities), but not always successfully. Creating a unit responsible for participation in an institution (or its absence) affects the possibility of transferring tested foreign practices to Poland [Olech, Sobiesiak-Penszko 2013, p. 21; Domański 2010, pp. 48-49; Raport Końcowy... 2011, p. 146]. Poorly organised consultations do not produce meaningful results, hence begins the vicious circle in which the organisers themselves become convinced that social participation does not make sense. It is considered to be only an aditional burden of work on the officials part and an additional budget expenditure. In subsequent activities, they leave participation out or limit its scope [Boryczko 2016a, p. 133; Raport Końcowy... 2011, p. 143].

A mistake resulting from a poorly organised process, but also from a misunderstanding of the idea of participation itself, is the organising of a formal process, resulting from the provisions of law that is not aimed at solving problems but only at the fulfilment of formal requirements. These requirements are understood as obtaining a one-way transfer of information [Rembarz 2016, pp. 27-28; Bukowski 2014; Długosz, Wygnański 2005, p. 10; Jasiecki 2015, p. 110-111; Parnes 2014, p. 130; Badanie efektywności... 2011, p. 7]. In such a case, we can speak of minimal participation, using the simplest, least demanding and involving forms of participatory activities [Rembarz, Martyniuk-Pęczek 2016, p. 126, pp. 133-134; Olech, Sobiesiak-Penszko 2013, pp. 5-6, 9-10; Szaja 2015, p. 295; Boryczko 2016a, p. 133; WiktorskaŚwięcka 2013].

The formalisation of participation and insufficient devolution of decision-making processes may also result from the attitude of the local authorities which believe that winning elections entails full legitimacy to make decisions on their own. In such a case, even if the participation takes place (because it is required by law), it is ostensible and apparent and its results are not taken into account in decision-making processes.

The fourth group of obstacles consists of different legal requirements for various participatory processes. The participation related to the enacting of planning documentation (studies of conditions and directions spatial planning and local spatial development plans) is the most formalised [Legutko-Kobus, Jastrzębska 2014b]. The participation in the preparation and implementation of urban renewal programmes is highly formalised in terms of procedure, particularly when it is based on the Revitalisation Act [Hołuj, LegutkoKobus 2018]. External stakeholders do not always understand the differences in the ways of

\footnotetext{
${ }^{3}$ In this respect, the situation of local governments is very diverse and to a great extent depends on their human resources. It is possible to indicate "best practices" in this respect, i.e. local governments with institutions for participation and social communication, and even tools for periodical consultation of residents (e.g. the Citizens' Committee of the city of Olsztyn [Olsztyński Panel Obywatelski], http://olsztyn.panelobywatelski.pl/). The participatory research and observations of the authors allow them to state that in smaller local governments participation is the domain of people involved in spatial planning or environmental protection. Therefore, due to the multitude of other professional duties, it is treated as a secondary issue. Especially that those dealing with it do not feel competent to conduct a continuous dialogue with stakeholders, but rather focus on ad hoc, action-oriented and required by law consultations of specific documents (e.g. spatial development plans).
} 
conducting participation based on various types of documents, especially if consultations are conducted at the same time, without proper information on the differences (e.g. resulting from the time required for the consultations) and the tools adopted.

However, the single most demotivating practice for external stakeholders is not taking into account the results of consultations in later actions - ignoring the results or the inability to make use of them for the public benefit [Bukowski 2014; Długosz, Wygnański 2005, p. 10, 21; Noworól, Noworól, Hałat 2012, p. 27].

To sum up, we can say that there are different attitudes towards participation in social activities in Poland, both on the part of the citizens and of the authorities. Conflicting attitudes generate certain interactions, e.g. the authorities lose interest in developing participation in areas characterised by a lack of public interest. On the other hand, in areas where the authorities undervalue the social impact on their decisions, social initiatives are born, often as a kind of rebellion. They can be examples of initiatives developed to achieve a public interest or can simply be a way of solving the particular issues of a selected group in a community [Jasiecki 2015, pp. 113-114; Badanie efektywności... 2011, p. 6].

\section{Participation in the process of revitalisation of selected cities}

9 sub-regional cities were surveyed using a questionnaire and analysed ( 5 in the Lesser Poland region, i.e. Chrzanów, Nowy Sącz, Nowy Targ, Olkusz and Oświęcim, and 4 in the Mazovia region, i.e. Ciechanów, Płock, Radom, Siedlce). In the context of participation, these cities differ in terms of the legal bases adopted for the development of revitalisation programmes. In Lesser Poland, all the programmes were developed on the basis of the provisions of the Revitalisation Act, while only one programme in the analysed Mazovian cities was based on the same regulations (Płock). The remaining ones were designed on the basis of the Act on municipal government. However, they take into account the provisions of the Revitalisation Act in terms of participation. As indicated by the data presented in Table 1, the analysed cities are characterised by different demographic potentials and social capital indexes expressed by participation in local government elections (which can be considered to be an indicator of local social commitment). Both regions were characterised by a higher voter turnout than the Polish average. An analysis of the data shows that some cities achieved a lower turnout rate than the regional average - in Lesser Poland a lower turnout was recorded in Chrzanów, Nowy Targ and Oświęcim. The lowest turnout rate in Mazovia was recorded in Płock and Radom. All the analysed cities adopted programmes of cooperation with non-governmental organisations and with entities operating for the public benefit. The programmes introduce, among other things: the requirement to consult city council resolutions concerning the statutory tasks of these organisations and entities; municipalities having to cooperate with the organisations and creating joint task forces.

Among the analysed cities, different percentages of territory and population were included in the revitalisation programmes (Table 1) - this factor may also create an obstacle to participation. Research indicates that one of the difficulties in the process of participation 
is successfully attracting people to take part in participatory activities [Box 2015, p. 100]. In consequence, it is also not easy to ensure the participation of representatives of as many as possible of the groups living in or using the area subject to urban renewal and of groups that may contribute to the creation of a better revitalisation programme. Success in this respect is, of course, a derivative of the level of local social capital, but also of the locally existing differences in economic, social and cultural capital. The larger the differences, the more difficult it is to communicate [Weryński 2016, p. 87]. The composition of those taking part in the

Table 1. Analysis of Mazovian and Lesser Poland cities' participation in the revitalisation process

\begin{tabular}{|c|c|c|}
\hline Name of the centre / population & & Turnout in the last local \\
\hline $\begin{array}{l}\text { Area and population of the area } \\
\text { subject to revitalisation } \\
\text { (\% of the municipality area/ } \\
\% \text { of the population of the } \\
\text { municipality) }\end{array}$ & $\begin{array}{l}\text { Person(s)/organisational cell(s) } \\
\text { responsible for managing matters } \\
\text { related to revitalisation }\end{array}$ & $\begin{array}{l}\text { (1st round 2014, } \\
\text { elections to the } \\
\text { municipal council) } \\
\text { Turnout: } \\
47.34 \% \text { in Poland } \\
\text { In the Lesser Poland } \\
\text { region: } 48.65 \% \\
\text { In the Mazovia region: } \\
51.20 \% \text {. }\end{array}$ \\
\hline Chrzanów / pop. 37,291 & $\begin{array}{l}\text { Responsibilities concerning revitalisation } \\
\text { were added to the tasks of an existing } \\
\text { position (The Department for Aid } \\
\text { Funds and Investments) [Wydział } \\
\text { Funduszy Pomocowych i Inwestycji] }\end{array}$ & $40.34 \%$ \\
\hline Nowy Sącz / pop. 83,993 & \multirow[b]{2}{*}{ none designated } & \multirow[b]{2}{*}{$49.95 \%$} \\
\hline 200.77 ha (3.5\%) / 8.076 (9.8\%) & & \\
\hline Nowy Targ / pop. 33,412 & \multirow[b]{2}{*}{ none designated } & \multirow[b]{2}{*}{$46.34 \%$} \\
\hline 248.42 ha $(4.86 \%)$ / 9,390 (28.93\%) & & \\
\hline Olkusz / pop. 36,122 & \multirow[b]{2}{*}{$\begin{array}{l}\text { Responsibilities concerning revitalisation } \\
\text { were added to the tasks of an existing } \\
\text { position (The Office for Coordination } \\
\text { of EU funds UMiG Olkusz) [Biuro } \\
\text { Koordynacji Funduszy Unii Europejskiej } \\
\text { UMiG Olkusz]. Task force for the urban } \\
\text { renewal was established }\end{array}$} & \multirow[b]{2}{*}{$50.82 \%$} \\
\hline 242.75 ha (1.62\%) / 11.096 (22.5\%) & & \\
\hline
\end{tabular}


Dominika Hołuj, Paulina Legutko-Kobus

\begin{tabular}{|c|c|c|}
\hline Name of the centre / population & & Turnout in the last local \\
\hline $\begin{array}{l}\text { Area and population of the area } \\
\text { subject to revitalisation } \\
\text { (\% of the municipality area/ } \\
\% \text { of the population of the } \\
\text { municipality) }\end{array}$ & $\begin{array}{l}\text { Person(s)/organisational cell(s) } \\
\text { responsible for managing matters } \\
\text { related to revitalisation }\end{array}$ & $\begin{array}{l}\text { (1st round 2014, } \\
\text { elections to the } \\
\text { municipal council) } \\
\text { Turnout: } \\
47.34 \% \text { in Poland } \\
\text { In the Lesser Poland } \\
\text { region: } 48.65 \% \\
\text { In the Mazovia region: } \\
51.20 \% \text {. }\end{array}$ \\
\hline Oświęcim/ pop. 38.972 & \multirow{2}{*}{$\begin{array}{l}\text { Responsibilities concerning revitalisation } \\
\text { were added to the tasks of an existing } \\
\text { position (City Development Office) }\end{array}$} & \multirow[b]{2}{*}{$45.11 \%$} \\
\hline $\begin{array}{c}307.83 \text { ha }(10.26 \%) / \\
10.896(27.63 \%)\end{array}$ & & \\
\hline Ciechanów / pop. 44.506 & \multirow{2}{*}{$\begin{array}{l}\text { External Relations and Strategic Actions } \\
\qquad \text { Unit }\end{array}$} & \multirow{2}{*}{$52.79 \%$} \\
\hline 291.68 ha $(8.97 \%) / 11.821$ (26.9\%) & & \\
\hline Płock/ pop. 121,731 & \multirow[b]{2}{*}{$\begin{array}{l}\text { A separate organisational unit was } \\
\text { established: The Department for } \\
\text { Revitalisation and Aestheticisation of the } \\
\text { City (within the Department for } \\
\text { Development and Economic Policy of } \\
\text { the City) }\end{array}$} & \multirow[b]{2}{*}{$45.89 \%$} \\
\hline $\begin{array}{l}700.9 \text { ha }(7.96 \%) / \\
34.105(27.90 \%)\end{array}$ & & \\
\hline Radom/ pop. 216,159 & \multirow{2}{*}{$\begin{array}{l}\text { A three-person task force for } \\
\text { revitalisation was established within the } \\
\text { Department for Investments of the City } \\
\text { Hall }\end{array}$} & \multirow[b]{2}{*}{$41.79 \%$} \\
\hline $\begin{array}{c}331.8 \mathrm{ha},(2.96 \%) / \\
26.652(12.76 \%)\end{array}$ & & \\
\hline Siedlce / pop. 76,942 & \multirow{2}{*}{$\begin{array}{l}\text { Responsibilities concerning revitalisation } \\
\text { were added to the tasks of an existing } \\
\text { position (The Inspector for } \\
\text { Revitalisation of Monuments) }\end{array}$} & \multirow[b]{2}{*}{$52.06 \%$} \\
\hline $\begin{array}{c}260.2 \text { ha }(8.2 \%) / \\
11.624(15.2 \%)\end{array}$ & & \\
\hline
\end{tabular}

Source: own elaboration on the basis of municipal/local revitalisation programmes, a questionnaire survey conducted in the city halls and public information bulletins of municipalities. Population data for 2016 - Local Data Bank of GUS. Data on voter turnout based on the National Electoral Commission, http://samorzad 2014.pkw.gov.pl/359_Rady_gmin 
participatory activities may therefore reflect the social exclusions occurring in an area. Excluded groups, struggling with problems, do not participate in discussions about their problems. They cannot be forced to do so, which is another dimension of exclusion - this time from participation in discussion [Baranowska, Frankowski, Grabkowska, Sagan 2014, p. 124]. Their absence from participation often means not being able to express the problems faced by these groups [Długosz, Wygnański 2005, p. 10].

One of the commonly encountered obstacles to efficient participation in revitalisation is limiting it to renovation, modernization, conservation of a monument, restoration. This results in the participation of those people and entities who want to acquire funds for renovation and investment activities and not of those who could contribute to solving social problems. In such an approach, the revitalisation is reduced to hard measures which are co-financed by EU funds and are directly related to the improvement of spatial parameters (filling the "renovation gap") [Rembarz 2016, pp. 27-28; p. 34; Domański Gwosdz 2010, p. 53; Boryczka 2016b, p. 168].

The position of the units for revitalisation within the organisational structures of institutions may suggest how the revitalisation process is perceived. The data presented in Table 1 allows for the following statements to be made:

- in two centres the responsibility for issues related to the revitalisation was not attributed at all (Nowy Sącz, Nowy Targ) - this should definitely not be the case;

- in four other cities these duties were assigned to the unit or person in charge of obtaining EU funds and/or investment matters (Chrzanów, Olkusz, Ciechanów, Radom);

- in one case the name of a position related to the revitalisation matters was associated with its material dimension - in Siedlce the position of Inspector for Revitalisation of Monuments was created (significant narrowing of the concept);

- in two cities the responsibility for revitalisation was included in the structure of tasks of departments dealing with the development of the city centre (Oświęcim, Płock) [Hołuj, Legutko-Kobus 2018].

The analysis allows us to state that in all the cities the participatory procedures were carried out in accordance with the provisions of the Revitalisation Act. The number of procedures applied, the adopted channels of information and forms of consultation differed, assumedly so as to adapt to the local conditions (Table 2).

The information policy in specific cities and the way of reaching out to the stakeholders were based both on mandatory forms (all offices posted information about consultations on their websites and in a customary manner on the notice boards of municipalities), as well as on optional ones, e.g. personal invitations, leaflets, posters, mailing lists (at least one optional form of information was used). 
Table 2. The utilised forms of public consultations - at particular stages of a revitalisation programme

\begin{tabular}{|c|c|c|c|}
\hline City & $\begin{array}{c}\text { Determination and } \\
\text { diagnosis of degraded } \\
\text { areas - total number of } \\
\text { forms of consultation } \\
\text { utilised }\end{array}$ & $\begin{array}{l}\text { Consultations on a project } \\
\text { of revitalisation programme } \\
\text { - total number of forms of } \\
\text { consultation utilised }\end{array}$ & $\begin{array}{l}\text { Consultations on a resolution } \\
\text { concerning the revitalisation } \\
\text { committee - total number of } \\
\text { forms of consultation utilised }\end{array}$ \\
\hline \multicolumn{4}{|l|}{ Lesser Poland } \\
\hline Chrzanów & 4 & 3 & 3 \\
\hline Nowy Sącz & 5 & 4 & 3 \\
\hline Nowy Targ & 3 & 5 & 3 \\
\hline Olkusz & 4 & 3 & 3 \\
\hline Oświęcim & 3 & 3 & 3 \\
\hline \multicolumn{4}{|l|}{ Mazovia } \\
\hline Ciechanów & 6 & 4 & not applicable \\
\hline Płock ${ }^{*}$ & 6 & 6 & 2 \\
\hline Radom & 5 & 7 & not applicable \\
\hline Siedlce & 4 & 4 & not applicable \\
\hline
\end{tabular}

* In the Mazovia region, a revitalisation committee was only established in Płock.

Source: own elaboration on the basis of the results of questionnaires and reports of conducted social consultations

An analysis of data from Table 2 clearly indicates that the largest number of forms of stakeholder involvement is used at the beginning of the process when the the degraded area is delimited along with the area subject to revitalisation. At this stage each city gave the opportunity to submit written remarks as a form of consultation (mandatory form resulting from the Act). In addition, meetings (7 cities), surveys (7 cities) and oral comments (6 cities) were very popular. The least popular forms of consultation were interviews and study tours, utilised only in one city.

Two cities (Nowy Targ and Radom) used more forms of consultation at the stage of consulting the draft of the revitalisation programme than at the stage of determining the area subject to revitalisation. Apart from the possibility of submitting written remarks available in each city (obligatory), other popular forms were oral comments (7 cities), questionnaires (6 cities), meetings (6 cities). It is worth noting that at this stage 4 cities organised a debate and 3 cities organised workshops and study walks.

The fewest forms were used during the consultations of a resolution pertaining to the revitalisation committee: cities in Lesser Poland utilised 3 forms each, while Płock used only 2. Apart from the obligatory written remarks, the following forms were used: meetings, debates, questionnaires and oral comments. 
A detailed analysis indicates that the largest number of people took part in the surveys (the largest number was conducted on a group of 500 people in Siedlce), much fewer in workshops and debates (attendance rarely exceeded 50 participants, and there were debates in which only few took part). Citizens were the least involved in consulting the resolution pertaining to the establishing of Revitalisation Committees which are supposed to be participatory bodies with advisory functions [Hołuj, Legutko-Kobus 2018].

In order to analyse the efficiency of participation, the following assumptions were formulated:

1. participation entails a diverse structure of entities submitting proposals for revitalisation projects;

2. participation contributes to an increase in the total number of projects pertaining to social issues (soft measures);

3. the participation of external stakeholders entails the financial engineering of projects with various sources of financing.

Re 1. The structure of entities that submitted proposals for revitalisation projects differs in the analysed cities. In some, projects implemented or co-implemented by a municipality and its units, or other self-government entities (e.g. the county government) dominate. Other cities, on the other hand, are characterised by a very large diversity of entities. Nowy Sącz is an example of such a city (projects were submitted by, among others: municipal units with a diversified structure of tasks - educational, cultural, social; many entities from the third sector; private entities; church institutions of various religions). The structure of entities in Oświęcim is also quite diverse. The list of basic projects in Chrzanów consists mainly of tasks carried out by the local government and its units, as well as by a number of private entities with a monolithic structure. These are only homeowners' associations planning renovations in their buildings.

Re 2. In the analysed cities the structure of projects is dominated by infrastructure projects, both in quantitative and nominal terms (Table 3). Infrastructure projects accounted for as much as $90 \%$ of all tasks in some cities of Lesser Poland (Oświęcim), although the most common ratio was $70 \%$ of investment projects to about $30 \%$ of soft (social) projects. In Mazovia, the largest share of infrastructure projects within the revitalisation programmes was recorded in Ciechanów (76\%), the smallest (53\%) in Siedlce.

The division of projects into those managed by the local government and those submitted by external stakeholders shows that municipalities differentiated their structural tasks more often (sometimes even reaching a balance between the number of infrastructural and soft projects, as was the case in Chrzanów). As for projects submitted by external stakeholders, in some cities they consisted almost completely (or completely) of investment tasks (Chrzanów, Oświęcim). The situation was slightly different in Mazovia. Infrastructural projects definitely dominated among local government projects (90\%) only in Siedlce. External stakeholders in Siedlce submitted predominantly soft projects $(71 \%)$, while in Ciechanów and Radom only $23 \%$ and $24 \%$, respectively. 
Table 3. Structure of projects of revitalisation programmes in the analysed cities

\begin{tabular}{|c|c|c|c|c|c|c|c|c|}
\hline \multirow{2}{*}{$\stackrel{\mathscr{U}}{\stackrel{\mathscr{E}}{U}}$} & \multicolumn{2}{|c|}{ 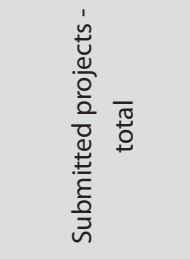 } & \multicolumn{2}{|c|}{ 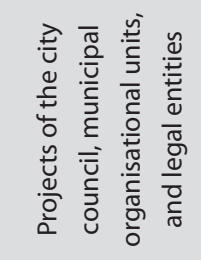 } & \multicolumn{2}{|c|}{ 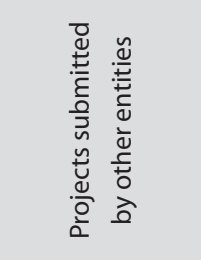 } & \multicolumn{2}{|c|}{ 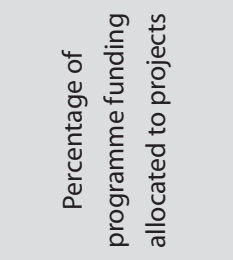 } \\
\hline & $\stackrel{\varpi}{\circ}$ & 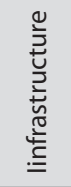 & $\underset{\sim}{\frac{t}{0}}$ & 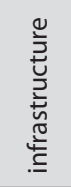 & $\underset{\sim}{ \pm}$ & 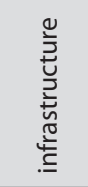 & 䒕 & 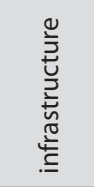 \\
\hline \multicolumn{9}{|c|}{ Lesser Poland } \\
\hline Chrzanów & $24 \%$ & $76 \%$ & $48 \%$ & $52 \%$ & $0 \%$ & $100 \%$ & $4 \%$ & $96, \%$ \\
\hline Nowy Sącz & $38 \%$ & $62 \%$ & $42 \%$ & $58 \%$ & $31 \%$ & $69 \%$ & $0,05 \%$ & $99,95 \%$ \\
\hline Nowy Targ & $31 \%$ & $69 \%$ & $26 \%$ & $74 \%$ & $32 \%$ & $68 \%$ & $2 \%$ & $98 \%$ \\
\hline Olkusz & $31 \%$ & $69 \%$ & $20 \%$ & $80 \%$ & $44 \%$ & $56 \%$ & $31,5 \%$ & $68,5 \%$ \\
\hline Oświęcim & $10 \%$ & $90 \%$ & $31 \%$ & $69 \%$ & $3 \%$ & $97 \%$ & $3 \%$ & $97 \%$ \\
\hline \multicolumn{9}{|c|}{ Mazovia } \\
\hline Ciechanów & $24 \%$ & $76 \%$ & $24 \%$ & $76 \%$ & $23 \%$ & $77 \%$ & $3 \%$ & $97 \%$ \\
\hline Płock & $39 \%$ & $61 \%$ & $32 \%$ & $68 \%$ & $47 \%$ & $53 \%$ & $8 \%$ & $92 \%$ \\
\hline Radom & $25 \%$ & $75 \%$ & $29 \%$ & $71 \%$ & $24 \%$ & $76 \%$ & $1 \%$ & $99 \%$ \\
\hline Siedlce & $46 \%$ & $53 \%$ & $10 \%$ & $90 \%$ & $71 \%$ & $29 \%$ & $20 \%$ & $80 \%$ \\
\hline
\end{tabular}

Source: own elaboration on the basis of the local/municipal revitalization programmes

The disproportion between the infrastructural and soft tasks is even more visible in their nominal value. In most cases the total value of the infrastructure projects amounted to over 95\% of all planned expenditures on the implementation of the revitalisation programs in the analysed cities of Lesser Poland (Chrzanów, Nowy Sącz, Nowy Targ, Oświęcim). ${ }^{4}$ The nominal value of infrastructure projects averaged at $92 \%$ in all cities of the Mazovia region and ranged from $99 \%$ in Radom to $80 \%$ in Siedlce.

\footnotetext{
${ }^{4}$ When calculating the value of infrastructural and soft projects for each city, mixed projects were excluded from the analysis due to the impossibility of separating the planned costs of individual parts of the project. This was the case with only a few projects from different cities and in effect did not have a significant impact on the reliability of the conclusions.
} 
Re 3. When analysing the issue of financing projects within the framework of revitalisation programmes, it should be noted that a desire to fully exploit EU funds may lead to a very strict adherence to the guidelines, fixation on deadlines or on fitting into the list of subsidised activities. This may result in getting rid of the project parts that are not fully in line with the call for proposals requirements, even if they are important for the revitalisation. Another effect may be the manipulation of participants [Rembarz, Martyniuk-Pęczek 2016, p. 127; Malikowski, Malikowski 2016, p. 16; Malikowski, Malikowski 2016, p. 16; Przywara 2013, p. 63; Raport Końcowy... 2011, p. 146; Domański, Gwosdz 2010, p. 55; Koczanowicz-Hondzyńska 2009; Ciesiółka 2013, p. 162].

The third sector is also willing to adhere to the EU guidelines, as it is underfunded and its existence relies on subsidies and grants. The struggle for funds is the struggle for survival [Herbst 2006, p. 26]. Moreover, basing the financing of the revitalisation programmes predominantly on EU funds (the acquisition of which takes place mainly through competitive procedures) also entails the risk of failing to complete the tasks if the financing cannot be obtained from the only source taken into account [Matysiak 2013, p. 65; Bukowski 2014; Ciesiółka 2013, p. 162].

The analysis of the current revitalisation programmes in selected Mazovian and Lesser Poland cities illustrates this problem very well. The basic and complementary projects included in the programmes are predominantly planned to be co-financed with funds, the acquisition of which is not certain. Depending on the city, these are either mainly EU funds (ERDF, ESF) or national external funding. The cities which planned to co-finance all their tasks using EU funds are Nowy Targ and, in the case of infrastructural tasks, ${ }^{5}$ Chrzanów. The situation is almost the same in Nowy Sącz and Olkusz (only a few projects in each city are not based on an uncertain external source of financing).

In the cities of the Mazovia region not all the projects are dependent on EU funding. However, the projects financed from other sources (municipal, county or regional budgets, entrepreneurs' or NGOs' funds) are minor soft projects. The more expensive infrastructure projects are mostly based on EU funding (this is best illustrated by the example of the city of Radom). As much as $85 \%$ of the tasks in Oświęcim are not intended to be co-financed using EU funds. In their case, however, the expectation was to obtain external national funds and targeted credits or loans (mainly for tasks related to achieving a positive environmental effect). ${ }^{6}$ EU funds are the most common form of non-returnable co-financing in the analysed cities.

Other external and domestic identified sources of financing are: programmes funded by the Ministry of Culture and National Heritage, the Ministry of the Interior and Administration - pertaining to the preservation and development of cultural heritage of national and ethnic

\footnotetext{
${ }^{5}$ In the case of soft tasks, the structure of financing was not specified, therefore no conclusion could be reached.

${ }^{6}$ It should be added that the city of Oświęcim partially based its revitalisation program on external national funds from the Oświęcim Strategic Government Programme. In this case, obtaining the funds is more probable than if they came from other external sources. However, the projects must be in line with the objectives of the programme.
} 
minorities, the Civic Initiatives Fund, Regional Funds for Environmental Protection and Water Management, the National Fund for Environmental Protection and Water Management, the thermomodernization fund of Bank Gospodarstwa Krajowego; the Physical Education Development Fund and the Government Programme for Social Participation of Senior Citizens. It should be noted that these are to a large extent thematic programmes which can only be used to implement specific types of tasks. The availability of such funds is important because it enables specific problems to be solved. On the other hand, it poses the threat of modifying (adjusting) the planned tasks in order to obtain funds.

Projects to be subsidised by private foundations are much less frequent. Nowy Sącz is an example of a city that is planning to utilise such funds.

The most popular form of financial engineering is the use of the project submitter's own resources and one of the external sources (EU or other national funds). For example, in Chrzanów, apart from the project submitters' own resources, one can mainly find EU funds. The third source of co-financing appears much less frequently in the analysed cities of Lesser Poland and Mazovia. These are either funds from different levels of local government (mainly county and regional), private funds or external repayable sources (credits or loans).

A clear correlation is visible between the degree of diversification of the structure of entities submitting revitalisation projects and the planned structure and sources of their financing. The diversity of entities, and in result diversity of the thematic scope of the proposed projects, translates into better (broader) possibilities of searching for diversified external sources of financing. This is due to the fact that many available external sources are allocated to specific tasks or entities. Nowy Sącz and Ciechanów are examples in which such a correlation is clearly visible.

\section{Conclusion}

Participation in the revitalisation process is crucial for diagnosing problems and developing projects that will aim at solving them. It is important that the interested parties are not excluded from the discussion but that they take an active part therein. Therefore, it is the responsibility of the local authorities to properly direct information (choice of information channels) and to ensure that external stakeholders can actively participate in the whole process. In order for the participation to have a chance of success, the other side must be involved and both need to strive for mutual consensus. Participation in the revitalisation process does not take place in a vacuum. It takes place in local government units that already have some (better or worse) experience in terms of participation. The quality of participation is also influenced by external factors related to its surroundings (including dependence on EU funds) and the quality of social capital which, as the analysis shows, is an obstacle in Poland.

The introduction of the Revitalisation Act obliged local governments to involve stakeholders more actively in the process of preparing and implementing revitalisation programmes. As indicated by the analysis of the selected cities of Lesser Poland and 
Mazovia, local governments fulfil the legal obligations, but mostly limit themselves to less engaging forms of participation. This translates into the following rungs of the Ladder of Citizen Participation: 3. Informing, 4. Consultation and 5. Placation [Arnstein 1969]. The Act guarantees the utilisation of weak forms of participation (mainly submission of remarks). The usage of more advanced forms depends on the individual decisions of the municipal authorities, on the external entities employed by the municipality to develop the programmes and often on the attitude of external stakeholders (as advanced participation does not contribute much and is not worthwhile to organise if the environment lacks potential and external stakeholders need to be coaxed to participate in this process).

The Revitalisation Act guarantees participation at every key stage of the process. In Polish circumstances, this is a change for the better, as such participation has not always been possible in the past. Before it is possible to determine whether the participation process is efficient, or if it only "fulfils" the procedures, some amount of time is required, especially in terms of the programmes' implementation. At the programmes' development stage in the analysed cities, the participation of inhabitants in participatory procedures can hardly be considered satisfactory (especially in more activating forms such as workshops or study walks). This state of affairs is influenced by the quality of social capital and, above all, by the low level of confidence in the authorities, i.e. the elements that are built (strengthened) over the years in an evolutionary manner.

\section{References}

Arnstein S.R., 1969, A ladder of citizen participation, Journal of the American Institute of Planners, 35, 4, pp. 216-224.

Badanie efektywności mechanizmów konsultacji społecznych. Raport końcowy - załącznik nr 5, 2011, Raport przygotowany na zlecenie Ministerstwa Pracy i Polityki Społecznej, Warszawa.

Baranowska A., Frankowski J., Grabkowska M., Sagan I., 2014, Miejska obywatelskość [in:] J. Sepioł (ed.), Przestrzeń życia Polaków, Raport opracowany przez zespół niezależnych ekspertów z inspiracji Prezydenta RP Bronisława Komorowskiego.

Billert A., 2014, Dezintegracja polskich miast i drogi wyjścia z kryzysu. Doświadczenia praktyczneCentrum Staromiejskie w Toruniu [in:] K. Derejski, J. Kubera, S. Lisiecki, R. Macyra (eds), Nowe życie w mieście? Dylematy rewitalizacji, Wyd. Naukowe Wydziału Nauk Społecznych UAM, Poznań, pp. 109-123.

Bleckley D., 2008, Assessing Participatory Development Processes Through Knowledge Building, SPNA Review, 4, 1, Grand Valley State University, pp. 21-36.

Boryczka E., 2016a, Partycypacja społeczna [in:] A. Nowakowska, Z. Przygodzki, A. Rzeńca (eds), EkoMiasto\#Społeczeństwo. Zrównoważony, inteligentny i partycypacyjny rozwój miasta, Wyd. Uniwersytetu Łódzkiego, Łódź, pp. 115-136. 
Boryczka E., 2016b, Rewitalizacja miast [in:] Z. Przygodzki (ed.), EkoMiasto\#Zarzadzanie. Zrównoważony, inteligentny i partycypacyjny rozwój miasta, Wyd. Uniwersytetu Łódzkiego, Łódź, pp. 167-193.

Bukowski J., 2014, Partycypacja, władza, skuteczność. Złoty trójkąt demokratycznego wspótrządzenia czy raczej "trójkąt bermudzki” (prezentacja „Śniadania u geografów”, 26.05.2014).

Ciesiółka P., 2013, Proces rewitalizacji miast i gmin aglomeracji poznańskiej. Planowanie i zarządzanie, Studia i Prace z Geografii i Geologii, 39, Bogucki Wydawnictwo Naukowe, Poznań.

Creighton J. L., 2005, The Public Participation Handbook. Making Better Decisions Through Citizen Involvement, Jossey Bass, Wiley and Sons [in print].

Czyż P., 2016, Organizacja procesu rewitalizacji z użyciem metody placemakingu na przykładzie projektu społecznej rewitalizacji Parku Świętopełka w Gdańsku, Biuletyn, 264, KPZK PAN, pp. 294-305.

Diagnoza Społeczna 2015. Warunki i jakość życia Polaków. Raport, J. Czapiński, T. Panek (eds), http://www.diagnoza.com/

Długosz D., Wygnański J., 2005, Obywatele współdecydują. Przewodni po partycypacji społecznej, Stowarzyszenie na rzecz Forum Inicjatyw Pozarządowych, Warszawa.

Domański B, Gwosdz K., 2010, Spojrzenie na problemy rewitalizacji miast w Polsce [in:] Z. Ziobrowski, W. Jarczewski (eds), Rewitalizacja miast polskich - diagnoza, t. 8, Instytut Rozwoju Miast, Kraków, pp. 45-56.

Domański B., 2010, Rewitalizacja miast polskich - wybrane zagadnienia [in:] Rewitalizacja miast polskich jako sposób zachowania dziedzictwa materialnego i duchowego oraz czynnik zrównoważonego rozwoju. Podsumowanie projektu, Instytut Rozwoju Miast, Kraków, pp. 23-49.

Dzieniszewska-Naroska K., 2011, „Odwołać wójta!”, Czyli o narodzinach partycypacji [in:] A. Olech (ed.), Partycypacja społeczna. O uczestnictwie obywateli w życiu wspólnoty lokalnej, Instytut Spraw Publicznych, Warszawa, pp. 112-129.

Florys K., Gałek O., Jarzębska A., Kazior B., 2016, Partycypacja milowy krok do rozwoju lokalnego, Fundacja MiLA, Kraków.

Gawroński H., 2010, Konsultacje społeczne jako forma partycypacji w zarządzaniu strategicznym jednostkami samorządu terytorialnego, Współczesne Zarządzanie, 1, Kwartalnik Środowisk Naukowych i Liderów Biznesu. 
Gorączko J., 2016, Analiza zjawiska partycypacji społecznej w wybranych polskich miastach jako narzędzia komunikacji społecznej, Media - Kultura - Komunikacja Społeczna, 12, 3, pp. 13-29.

Górski A.S., 2016, Znaczenie partycypacji społecznej w procesie rewitalizacji, Prace Naukowe Uniwersytetu Ekonomicznego we Wrocławiu, 443, pp. 89-93.

Grabowska B., 2003, Sfera publiczna - zbyteczna czy niezbędna w państwie liberalnym? FiloSofija, 1, 3, pp. 193-192.

Grabowski J., 2014, Dobre praktyki usuwania barier rewitalizacji terenów zdegradowanych [in:] B. Białecka (ed.), Zrównoważona rewitalizacja terenów zdegradowanych, GIG, Katowice, pp. 140-154.

Graham J., Amos B., Plumptre T., 2003, Principles for Good Governance in the 21st Century, Policy Brief, 15, Institute On Governance, Ottawa.

Grodzicki M., 2015, Dlaczego grupom udaje się podejmować działania? Przedstawienie teorii działań zbiorowych Elinor Ostrom, Ekonomia Społeczna, 1, pp. 66-78 [DOI: 10.15678/ES.2015.1.05].

Herbst J., 2006, Kondycja sektora ekonomii społecznej w Polsce 2006, Stowarzyszenie Klon/Jawor, Warszawa.

Hołuj D., 2014, Wizje planistów a oczekiwania użytkowników przestrzeni miejskiej: konfliktogenność procesu uchwalania planów miejscowych w wybranych obszarach polskich metropolii, Biuletyn, 253, KPZK PAN, pp. 45-52.

Hołuj D., 2016, Social Participation as a Tool for Managing Functional and Spatial Changes. Examples of Selected Centres of Small and Medium-Sized Towns in Poland, Journal of Settlements and Spatial Planning, 7, 2, pp. 113-123.

Hołuj D., Hołuj A., 2016, Partycypacja społeczna w planowaniu przestrzennym. Studium przypadku krakowskich osiedli Dywizjonu 303 oraz II Pułku Lotniczego, Zarządzanie publiczne, 3, 35, pp. 249-262 [DOI:10.4467/20843968ZP.17.020.5522].

Hołuj D., Legutko-Kobus P., 2018, Partycypacja jako element rewitalizacji (przykłady miast z województwa małopolskiego i mazowieckiego) [in print].

Jasiecki K., 2015, Problemy partycypacji społecznej w Polsce $i$ ich wptyw na polityke publiczna, Studia z Polityki Publicznej, 3, SGH, Warszawa, pp. 101-119.

Jastrzębska E., Legutko-Kobus P., 2014a, Rola i działania biznesu na rzecz budowania kapitału społecznego w Polsce, Mazowsze. Studia Regionalne, 17, pp. 49-75. 
Jessop B., 2007, Promowanie „dobrego rzadzenia” i ukrywanie jego słabości: refleksja nad politycznymi paradygmatami i politycznymi narracjami w sferze rzadzenia, Zarządzanie Publiczne, 2, 2, pp. 3965.

Kaczmarek S., 2001, Rewitalizacja terenów poprzemysłowych. Nowy wymiar w rozwoju miast, Wyd. Uniwersytetu Łódzkiego, Łódź.

Kaźmierczak T., 2011, Partycypacja publiczna [in:] Decydujmy razem. Udział społeczności lokalnych w podejmowaniu decyzji publicznych, Fundacja Fundusz Współpracy, Warszawa.

Koczanowicz-Chondzyńska J., 2009, Rewitalizacja - biuletyn FISE, Fundacja Inicjatyw Społeczno-Ekonomicznych, Warszawa.

Kopeć M., 2010, Rewitalizacja miejskich obszarów zdegradowanych, Monografie Prawnicze, Wyd. C.H. Beck, Warszawa.

Kotus J., 2014, Partycypacja społeczna w zarzadzaniu miastem. Pomiędzy wykluczeniem społecznym a zaangażowaniem, Studia miejskie, 13, 4, pp. 37-45.

Kozłowski S., Wojnarowska A., 2011, Rewitalizacja zdegradowanych obszarów miejskich. Zagadnienia teoretyczne, Wyd. Uniwersytetu Łódzkiego, Łódź.

Kwiatkowski K., 2015, W stronę interdyscyplinarnych metod konsultacji i partycypacji społecznych. Deliberacja - metajęzyki- „centra odrodzenia miast” [in:] M. Malikowski, M. Palak, J. Halik (eds), Zmiany w przestrzeni współczesnych miast, Wyd. Uniwersytetu Rzeszowskiego, Rzeszów, pp. 97-110.

Legutko-Kobus P., 2011, Kapitat ludzki i społeczny w rozwoju regionalnym [in:] Z. Strzelecki (ed.), Gospodarka regionalna i lokalna w Polsce. Czynniki i bariery, Oficyna Wydawnicza SGH, Warszawa, pp. 113-130.

Legutko-Kobus P., Jastrzębska E., 2014 b, Partycypacja $i$ kapitat społeczny jako determinanty wdrażania rozwoju zrównoważonego w planowaniu przestrzennym [in:] A. Maciejewska (ed.) Współczesne uwarunkowania gospodarowania przestrzenia-szanse i zagrożenia dla zrównoważonego rozwoju. Społeczny wymiar gospodarowania przestrzenia, Monografie Naukowe Wydziału Geodezji i Kartografii PW „Gospodarka Przestrzenna”, 6, pp. 38-47.

Lewenstein B., Schindler J., Skrzypiec R. (eds), 2010, Partycypacja społeczna $i$ aktywizacja w rozwiązywaniu problemów społeczności lokalnych, Wyd. Uniwersytetu Warszawskiego, Warszawa.

Lorens P., 2010, Rewitalizacja miast. Planowanie i realizacja, Politechnika Gdańska, Gdańsk. 
Lowndes V., Pratchett L., Stoker G., 2006, Diagnosing and Remedying the Failings of Official Participation Schemes: The CLEAR Framework, Social Policy \& Society, 5, 2, Cambridge University Press, pp. 281-291 [DOI:10.1017/S1474746405002988].

Malikowski M., Malikowski R., 2016, W kierunku usprawniania i zobiektywizowania metod konsultacji i partycypacji społecznej w projektach miejskich. Przykłady Rzeszowa i Kielc [in:] M. Malikowski, B. Szluz (eds), Problemy społeczno-przestrzenne współczesnego Rzeszowa, Wyd. Uniwersytetu Rzeszowskiego, pp. 13-24 [DOI 10.15584/978-83-7996-337-9_2].

Markowski T., 2007, Rynkowe podstawy procesów rewitalizacji miast [in:] P. Lorens (ed.), Rewitalizacja miast w Polsce. Pierwsze doświadczenia, Biblioteka Urbanisty, 10.

Markowski T., 2015, Zintegrowane plany rozwoju warunkiem sprawnego zarzadzania miejskimi obszarami funkcjonalnymi [in:] J. Woźniak (ed.), Świat wspótpracy - świat konfrontacji, Urząd Marszałkowski Województwa Małopolskiego, Kraków, pp. 289-300.

Matysiak M., 2013, Rewitalizacja jako szansa ożywienia turystycznego Żyrardowa, Problemy turystyki i rekreacji, 4, pp. 46-70.

Mazur S., Wygnański J.J., 2015, Jak zmieniaja się relacje państwa z organizacjami trzeciego sektora? [in:] S. Mazur, A. Pacut (eds), System finansowania organizacji pozarzadowych w Polsce, MSAP, Kraków, pp. 9-26.

Meisel-Dobrzański J., 2014, Wspótpraca NGO z sektorem publicznym - sposób na wzmocnienie demokracji i wzrost jakości polityk publicznych w Polsce, Zarządzanie Publiczne, 1, 25, pp. 73-90 [DOI:10.4467/20843968ZP.14.007.2180].

Nowak M., 2014, Śródka po siedmiu latach rewitalizacji. Metateoretyczny wtręt $i$ interpretacja socjologii procesu ożywiania miasta [in:] K. Derejski, J. Kubera, S. Lisiecki, R. Macyra (eds), Nowe życie w mieście? Dylematy rewitalizacji, Wyd. Naukowe Wydziału Nauk Społecznych UAM, Poznań, pp. 49-70.

Noworól A., Noworól K., Hałat P., 2012, Partycypacja społeczna w zarzadzaniu procesami rewitalizacji, Problemy Rozwoju Miast, 1, pp. 26-39.

OECD Territorial Outlook. Territorial Economy, 2001 Edition, OECD.

Olech A., Sobiesiak-Penszko P., 2013, Partycypacja publiczna w Polsce. Diagnoza i rekomendacje, Analizy i Opinie, Numer specjalny 3 luty 2013: „Decydujmy razem”, Instytut Spraw Publicznych, Warszawa.

Ostrom E., 1996, Crossing the great divide: Coproduction, synergy and development, World Development, 24, 6, pp. 1073-1087. 
Parnes J., 2014, Rola ICT w rozwoju lokalnego dialogu obywatelskiego [in:] M.W. Sienkiewicz, M. Sidor (eds), Dialog obywatelski. Formy, mechanizmy, bariery i perspektywy rozwoju, Wyd. Fundacji Centrum Rozwoju Lokalnego, Lublin, pp. 123-130.

Participatory governance and citizens' engagement in policy development, service delivery and budgeting, 2007, Committee of Experts on Public Administration. Sixth session, New York, 10-13 April, Item 3 of the provisional agend, Economic and Social Council, United Nations.

Parysek J.J., 2005, Miasta polskie na przełomie XX i XXI wieku. Rozwój i przekształcenia strukturalne, Bogucki Wydawnictwo Naukowe, Poznań.

Pawłowska K., 2012, Partycypacja społeczna w podejmowaniu decyzji dotyczacych przyrody w mieście, Zrównoważony Rozwój - Zastosowania, 3, pp. 49-70.

Przywara M., 2013, Od akcji do partycypacji [in:] A. Olech (ed.), Przepis na uczestnictwo. Diagnoza partycypacji publicznej w Polsce, 2, Instytut Spraw Publicznych, Warszawa, pp. 55-65.

Pudełko A., 2015, Partycypacja obywatelska w procesie rewitalizacji na przykładzie planowania Zintegrowanego Programu Rewitalizacji osiedla Nikiszowiec w Katowicach, Prace Geograficzne, 142, Instytut Geografii i Gospodarki Przestrzennej UJ, Kraków, pp. 89-103.

Raport Końcowy z Badania Efektywności Mechanizmów Konsultacji Społecznych, 2011, zlecenie Ministerstwa Pracy i Polityki Społecznej, Warszawa.

Rembarz G., 2016, Rewitalizacja Berlina i Lipska jako źródto inspiracji dla polskich praktyk rewitalizacyjnych, Biuletyn, 264, KPZK PAN, pp. 26-66.

Rembarz G., Martyniuk-Pęczek J., 2016, Urban mentoring jako nowa technika wspótpracy w procesie planowania partycypacyjnego, Biuletyn KPZK, 264, pp. 119-146.

Robinson F., Shaw K., Davidson G., 2005, On the Side of the Angels: Community Involvement in the Governance of Neighbourhood Renewal, Local Economy, 20, 1, pp. 13-26.

Rogaczewska M., Chodacz W., Hejda A., Prędkopowicz D., 2014, Planowanie rozwoju lokalnego z udziałem społeczności, Fundacja Fundusz Współpracy, Warszawa.

Rydzik W., 2009, Organizacja zarzadzania procesami rewitalizacji [in:] W. Rydzik (ed.), Rewitalizacja miast polskich - Aspekty prawne i organizacyjne zarzadzania rewitalizacja, t. 6, Instytut Rozwoju Miast, Kraków.

Sadura P., 2012, Za obywatelskie zaangażowanie trzeba płacić [in:] J. Erbel, P. Sadura (eds), Partycypacja. Przewodnik Krytyki Politycznej, Wyd. Krytyki Politycznej, Warszawa, pp. 40-50.

Schimanek T. 2015, Partycypacja obywatelska w społeczności lokalnej, FISE Fundacja Inicjatyw, Warszawa. 
Skalski K., 2007, Programy rewitalizacji w Polsce-bilans, perspektywy, zarzadzanie [in:] P. Lorens (ed.), Rewitalizacja miast w Polsce. Pierwsze doświadczenia, Biblioteka Urbanisty, 10.

Skrzypiec R., 2010, Konflikt lokalny motorem partycypacji społecznej i skutkiem zmiany - analiza wybranych przypadków: Oświęcim, Bieruń, Las i Kobiór [in:] B. Lewenstein, J. Schindler, R. Skrzypiec (eds), Partycypacja społeczna i aktywizacja w rozwiązywaniu problemów społeczności lokalnych, Wydz. Dziennikarstwa i Nauk Politycznych UW, Warszawa, pp. 126-142.

Solon-Lipiński M., 2015, Zmiany w nastawieniu Polaków do uczestnictwa w procesach podejmowania decyzji, (www.maszglos.pl).

Sowada T., Kotus J., 2015, Rola stowarzyszeń lokalnych w procesie partycypacji społecznej w zarzadzaniu miastem. Przykład Poznania, Studia i Prace z Geografii, 47, Bogucki Wydawnictwo Naukowe, Poznań.

Stypułkowski W., 2012, Aktywność obywatelska-pojęcie, pomiar i jej wpływ na rozwój regionalny, Zeszyty Naukowe WSEI, Seria Ekonomia, 5, 2, pp. 157-187.

Szaja M., 2015, Partycypacja lokalnej społeczności w kształtowaniu procesu rozwojowego w gminie, Zeszyty Naukowe Uniwersytetu Szczecińskiego, 881, Szczecin pp. 281-296 [DOI10.18276/ epu.2015.118-20].

Szczegóła L., 2003, Blokady społeczeństwa obywatelskiego w Polsce, Rocznik Lubuski 29, 1, pp. 11-26.

Sześciło D., 2014, Administracja i obywatele. W strone partnerstwa [in:] D. Sześciło (ed.), Administracja $i$ zarządzanie publiczne, Stowarzyszenie Absolwentów Wydziału Prawa i Administracji UW, Warszawa, pp. 236-256.

Sztompka P. 2007, Zaufanie: fundament społeczeństwa, Znak, Warszawa.

Theiss M., 2007, Krewni, znajomi, obywatele: kapitał społeczny a lokalna polityka społeczna, Wyd. A. Marszałek, Toruń.

Theiss M., 2010, System pozornie otwarty. O instytucjonalnych uwarunkowaniach lokalnej partycypacji politycznej w Polsce [in:] B. Lewenstein, J. Schindler, R. Skrzypiec (eds), Partycypacja społeczna i aktywizacja w rozwiazywaniu problemów społeczności lokalnych, Wyd. Uniwersytetu Warszawskiego, Warszawa, pp. 61-80.

Theiss M., 2011, Kapitał społeczny i wykluczenie społeczne, Polityka Społeczna, 5-6, pp. 43-47.

Urbanik A., Luber J., Chrzanowski O., Krzemińska A., 2012, Elementy partycypacji, FISE, Warszawa. 
Ustawa z dnia 9 października 2015 r. o rewitalizacji, tj. Dz.U. z 2017 r., poz. 1023.

Wańkowicz W., 2013, Podmiotowe uczestnictwo mieszkańców w procesach rewitalizacji przeciwdziałanie wykluczeniu społecznemu, Problemy Rozwoju Miast, 1, pp. 15-24.

Weryński P., 2016, Emergentne poziomy i przestrzenie w badaniach aktywnego obywatelstwa. Analiza morfogenetyczna, Zarządzanie Publiczne, 3, 37, pp. 80-92 [DOI: 10.15678/ZP.2016.37.3.06].

Wiktorska-Święcka A., 2013, Ku dialogowi obywatelskiemu w Polsce. Rada Dziatalności Pożytku Publicznego - 10 lat doświadczeń, MPIPS, Warszawa.

Wytyczne w zakresie rewitalizacji w programach operacyjnych na lata 2014-2020, 2015, Minister Infrastruktury i Rozwoju, Warszawa 3 lipca.

Yang K., Callahan K., 2007, Citizen Involvement Efforts and Bureaucratic Responsiveness: Participatory Values, Stakeholder Pressures and Administrative Practicality, Public Administration Review, 6, 2, pp. 249-264.

Ziobrowski Z., 2010, Cele i efekty projektu [in:] Rewitalizacja miast polskich jako sposób zachowania dziedzictwa materialnego $i$ duchowego oraz czynnik zrównoważonego rozwoju. Podsumowanie projektu, Instytut Rozwoju Miast, Kraków 2010, pp. 8-22. 


\section{Partycypacyjny model tworzenia programów rewitalizacji w Polsce}

\section{STRESZCZENIE}

Partycypacja to nieodzowny element opracowania i wdrażania programów rewitalizacji, który pozwala na prawidłowe zdiagnozowanie problemów i sformułowanie projektów rewitalizacyjnych, które będą zmierzały do ich rozwiązania. Wprowadzanie ustawy o rewitalizacji zobligowało samorządy do aktywniejszego włączania interesariuszy $\mathrm{w}$ proces przygotowania i realizowania programów rewitalizacji. Ustawa gwarantuje partycypację na każdym kluczowym etapie procesu - to $\mathrm{w}$ warunkach polskich zmiana $\mathrm{w}$ dobrym kierunku, w poprzednich perspektywach nie zawsze się to udawało. Jednak nie zawsze oznacza to sytuację, w której proces partycypacji jest rzeczywisty i efektywny, a nie tylko „zaspokaja” procedury. Wychodząc z tych przesłanek w artykule podjęto tematykę partycypacji w programach rewitalizacji, zarówno w ujęciu teoretycznym (jak może być zorganizowana partycypacja w ramach rewitalizacji, ze względu na uwarunkowania prawne, jakie bariery we wdrażaniu partycypacyjnego podejścia do opracowania programów rewitalizacji można zdiagnozować w Polsce), jak i w praktyce programowania w wybranych miastach województwa małopolskiego i mazowieckiego (jakie formy i narzędzia partycypacji zostały zastosowane na każdym etapie budowania programu rewitalizacji, czy zakres partycypacji przekłada się na strukturę projektów rewitalizacyjnych).

Tak sformułowane zagadnienia badawcze determinują zastosowane metody badań wykorzystane do opracowania artykułu, tj.: krytyczną analizę literatury przedmiotu, web i desk research, analizę porównawczą programów rewitalizacji wybranych miast, analizę wyników ankiety internetowej skierowanej do miast oraz obserwację uczestniczącą.

Słowa kluczowe: partycypacja, rewitalizacja, interesariusze, kapitał społeczny

Dominika Hołuj, PhD, Assistant Professor at the UNESCO Department of Cultural Heritage and Urban Studies, Department of Economic and Social History, Cracow University of Economics. Scientific interests: public participation as an important factor in solving problems at a local level and public participation in the processes of contemporary management of cultural heritage. The author has worked in expert teams dealing with the economy of cultural heritage. The teams were appointed by both Polish and foreign research institutions (OECD). Contact: holujd@uek.krakow.pl

Dominika Hołuj, dr, Zakład Dziedzictwa Kulturowego i Studiów Miejskich UNESCO, Katedra Historii Gospodarczej i Społecznej, Uniwersytet Ekonomiczny w Krakowie. Zainteresowania naukowe: partycypacja społeczna jako istotny czynnik rozwiązywania problemów na poziomie lokalnym oraz partycypacja społeczna w procesach współczesnego gospodarowania dziedzictwem kulturowym. Autorka pracowała w zespołach eksperckich zajmujących się tematyka ekonomiki dziedzictwa kulturowego powoływanych zarówno przez polskie jak i zagraniczne instytucje badawcze (OECD). Kontakt: holujd@uek.krakow.pl

Paulina Legutko-Kobus, PhD, Assistant Professor at the Department of Regional and Spatial Development, Warsaw School of Economics. Scientific secretary of the Spatial Development Committee of the Polish Academy of Sciences. Scientific interests (development programming, heritage management, participation, sustainable development) are combined with working as a trainer for territorial self-government units and being an expert in preparing strategic documents. Contact:plegut@sgh.waw.pl

Paulina Legutko-Kobus, dr, adiunkt w Katedrze Rozwoju Regionalnego i Przestrzennego, Szkoły Głównej Handlowej w Warszawie. Sekretarz naukowy Komitetu Przestrzennego Zagospodarowania Kraju PAN. Zainteresowania naukowe (programowanie rozwoju, zarządzanie dziedzictwem, partycypacja, rozwój zrównoważony) łączy z praktyką jako trener prowadzący szkolenia dla JST i ekspert opracowujący dokumenty strategiczne. Kontakt:plegut@sgh.waw.pl 